\title{
Classification of halo(alkali)philic and halo(alkali)tolerant methanotrophs provisionally assigned to the genera Methylomicrobium and Methylobacter and emended description of the genus Methylomicrobium
}

\author{
Correspondence \\ Marina G. Kalyuzhnaya \\ mkalyuzh@u.washington.edu
}

\section{Marina G. Kalyuzhnaya, ${ }_{1}^{1,2}$ Valentina Khmelenina, ${ }^{1}$ Bulat Eshinimaev, ${ }^{1}$ Dimitry Sorokin, ${ }^{3}$ Hiroyuki Fuse, ${ }^{4}$ Mary Lidstrom ${ }^{2,5}$ and Yuri Trotsenko ${ }^{1,6}$}
${ }^{1}$ G. K. Skryabin Institute of Biochemistry and Physiology of Microorganisms, Russian Academy of Sciences, Pushchino, Moscow region, 142292, Russia
${ }^{2}$ Department of Microbiology, University of Washington, Box 331750, Seattle, WA 98195-1750, USA
${ }^{3}$ S. N. Winogradsky Institute of Microbiology, Russian Academy of Sciences, Prospect 60-let Oktyabrya 7/2,117811, Moscow, Russia
${ }^{4}$ Institute for Biological Resources and Functions, National Institute of Advanced Industrial Science and Technology Tsukuba Central 6, 1-1-1 Higashi, Tsukuba, Ibaraki 305-8566, Japan
${ }^{5}$ Department of Chemical Engineering, University of Washington, Box 331750, Seattle, WA 98195-1750, USA
${ }^{6}$ Pushchino State University, Pushchino, Moscow region, 142290, Russia

Methanotrophic bacteria (methanotrophs) are a physiological subgroup of aerobic bacteria capable of utilization of methane as a single source of carbon and energy (Whittenbury et al., 1970). Methanotrophs are distributed

Abbreviation: ICM, intracytoplasmic membrane.

The GenBank/EMBL/DDBJ accession numbers for the $16 \mathrm{~S}$ rRNA gene sequences of strain $20 Z^{\top}$, strain $5 Z$, Methylomicrobium album $B G 8^{\top}$ and Methylomicrobium agile ATCC 35068 ${ }^{\top}$ are EF495157, AF096091, EU144025 and EU144026, respectively. ubiquitously in nature and play an important role in global carbon cycling. Specifically, they control methane emissions from a variety of environments (Higgins et al., 1980; Whalen \& Reeburgh, 1990; Hanson \& Hanson, 1996). The growing interest in environmental cycling of methane has resulted in characterization and description of novel methanotrophs (Bowman et al., 1997; Trotsenko \& Khmelenina, 2002a; Wise et al., 2001; Wartiainen et al., 2006; Dedysh et al., 2007). Over the past few decades, our knowledge of the diversity and distribution of methanotrophic bacteria in 
natural saline environments has been significantly expanded (Trotsenko \& Khmelenina, 2002b; Lin et al., 2004). It has been shown that methane-oxidizing microbial communities of saline and alkaline environments, such as saline ponds and soda lakes, are dominated by gammaproteobacterial (type I) methanotrophs (Trotsenko \& Khmelenina, 2002b; Lin et al., 2004; Nercessian et al., 2005). Several species of halophilic/-tolerant type I methanotrophic bacteria have been isolated in pure culture and characterized (Khmelenina et al., 1997; Kalyuzhnaya et al., 1998, 1999; Sorokin et al., 2000; Kaluzhnaya et al., 2001; Heyer et al., 2005). Some of the new isolates were described as novel taxa of methanotrophic bacteria, such as Methylohalobius crimeensis (Heyer et al., 2005) and Methylomicrobium buryatense (Kaluzhnaya et al., 2001), while others were tentatively referred to as members of Methylobacter or Methylomicrobium (Khmelenina et al., 1997; Fuse et al., 1998; Kalyuzhnaya et al., 1998; Sorokin et al., 2000).

The alkaliphilic, halophilic strains $20 \mathrm{Z}$ and $5 \mathrm{Z}$ (Khmelenina et al., 1997) and AMO1 (Sorokin et al., 2000) were isolated from highly alkaline soda lakes of Tuva (Russian Federation) and Kenya (Africa), respectively. Strain NI was isolated from marine mud (Hiroshima, Japan) (Fuse et al., 1998). A great deal of information regarding the structural, biochemical and molecular mechanisms of adaptation of these methanotrophic isolates to high $\mathrm{pH}$ and salt has been accumulated (Khmelenina et al., 1999; Trotsenko \& Khmelenina, 2002a, b; Reshetnikov et al., 2006). These extremophilic methanotrophs became attractive models for commercial production of fine chemicals from methane, such as ectoine, a multifunctional natural stabilizer (Trotsenko et al., 2005). They also have potential for biotechnological applications, such as bioremediation of trichloroethylene, dimethylsulphide and dimethyldisulphide (Fuse et al., 1998; Sorokin et al., 2000). Overall, detailed characterization of the physiological, morphological and phenotypic properties of these halophilic methanotrophs has indicated that they are related to each other (Trotsenko \& Khmelenina, 2002b). Here we compare the halo(alkalo)philic/-tolerant strains in terms of $16 \mathrm{~S}$ rRNA gene sequence phylogeny and DNADNA relatedness.

Strains used in this study are listed in Table 1. Methylomicrobium album ATCC $33003^{\mathrm{T}}$ and Methylomicrobium agile ATCC $35068^{\mathrm{T}}$ were obtained from the ATCC and were grown on basal nitrate-mineral salts (NMS) medium (Whittenbury et al., 1970). Strain AMO1 was obtained from the NCIMB as strain NCIMB 13566. Other strains were from the laboratory collections of Y.T. (strains 20Z and 5Z), H.F. (strain N1) and M.L. (Methylobacter marinus $\mathrm{A} 45^{\mathrm{T}}$ ). Strains 20Z, 5Z, AMO1 and Methylomicrobium buryatense 5G were grown on NMS medium to which $0.1 \mathrm{M} \mathrm{NaHCO}_{3}, 0.01 \mathrm{M} \mathrm{Na}_{2} \mathrm{CO}_{3}$ and $0.3 \mathrm{M} \mathrm{NaCl}$ were added. Methylobacter marinus $\mathrm{A}_{4} 5^{\mathrm{T}}$ was grown on basal NMS medium to which $0.3 \mathrm{M} \mathrm{NaCl}$ was added. Methylomicrobium sp. N1 was grown on artificial seawater medium (Cho \& Giovannoni, 2003). All strains were grown under a methane/air $(50: 50)$ atmosphere. The $\mathrm{G}+\mathrm{C}$ content of Methylomicrobium sp. N1 was determined by HPLC separation as described by Katayama-Fujimura et al. (1984) and was found to be $49.9 \mathrm{~mol} \%(n=3)$.

The 16S rRNA gene sequences of strains $\mathrm{NI}^{\mathrm{T}}$ and $\mathrm{AMO}^{\mathrm{T}}$ have been determined in previous studies (Fuse et al., 1998; Sorokin et al., 2000). The $16 \mathrm{~S}$ rRNA genes of strains $20 \mathrm{Z}^{\mathrm{T}}$ and $5 \mathrm{Z}$ were amplified by PCR using the $\mathrm{pA}^{\prime}$ and $\mathrm{pH}^{\prime}$ primer set (Edwards et al., 1989). PCR products were sequenced on both strands by using $\left[\gamma^{32} \mathrm{P}\right] \mathrm{ATP}$-labelled primers $\mathrm{pA}, \mathrm{pC}, \mathrm{pE}, \mathrm{pD}, \mathrm{pF}$ and $\mathrm{pH}$ (Edwards et al., 1989) and the fmol DNA Cycle Sequencing System (Promega), according to the manufacturer's protocol. The sequencing reactions were then subjected to PAGE, followed by

Table 1. Strains of moderately (halo)alkaliphilic methanotrophs

pMMO, particulate methane monooxygenase; sMMO, soluble methane monooxygenase. All strains use the ribulose monophosphate cycle.

\begin{tabular}{|c|c|c|c|c|}
\hline Strain & Growth optimum & $\mathrm{C}_{1}$ oxidation & $\begin{array}{c}\text { DNA G }+ \text { C content } \\
(\mathrm{mol} \%)\end{array}$ & Reference(s) \\
\hline \multicolumn{5}{|l|}{ Halophiles/neutrophiles } \\
\hline Methylomicrobium pelagicum AA- $23^{\mathrm{T}_{\star}}$ & $\mathrm{pH} 6.8 \dagger, 0.5-2 \% \mathrm{NaCl}$ & pMMO & 49.1 & $\begin{array}{l}\text { Sieburth et al. (1987); } \\
\text { Bowman et al. (1995) }\end{array}$ \\
\hline Methylomicrobium sp. NI & $\mathrm{pH} 8.1 \dagger, 3-5.6 \% \mathrm{NaCl}$ & $\begin{array}{r}\mathrm{pMMO} / \\
\mathrm{sMMO}\end{array}$ & $49.9 \neq$ & Fuse et al. (1998) \\
\hline \multicolumn{5}{|l|}{ Halo(alkali)philes } \\
\hline 'Methylobacter alcaliphilum' $20 \mathrm{Z}$ and $5 \mathrm{Z}$ & $\mathrm{pH} 9.0,1-3 \% \mathrm{NaCl}$ & pMMO & 47.8 & Khmelenina et al. (1997) \\
\hline $\begin{array}{l}\text { Methylomicrobium buryatense strains } 4 \mathrm{G}, 5 \mathrm{G}, 6 \mathrm{G} \text {, } \\
7 \mathrm{G} \text { and } 5 \mathrm{~B}^{\mathrm{T}}\end{array}$ & $\mathrm{pH} 7.5-9.5,0.75 \% \mathrm{NaCl}$ & $\begin{array}{r}\mathrm{pMMO} / \\
\mathrm{sMMO}\end{array}$ & $49-51$ & Kaluzhnaya et al. (2001) \\
\hline Methylomicrobium sp. AMO1 & $\mathrm{pH} 10,3 \% \mathrm{Na}^{+}$ & pMMO & 51 & Sorokin et al. (2000) \\
\hline
\end{tabular}

${ }^{*}$ No strain of this species is available.

$\dagger$ Reported growth conditions; the $\mathrm{pH}$ optimum was not determined.

$\ddagger$ Determined in this study. 
autoradiography. Since sequences of $16 \mathrm{~S}$ rRNA genes available from GenBank for Methylomicrobium album ACM $3314^{\mathrm{T}}$ (GenBank accession no. X72777) and Methylomicrobium agile ACM $3308^{\mathrm{T}}$ (X72767) have several missing bases, we amplified and resequenced 16S rRNA gene fragments for these type strains as described previously (Miller et al., 2005). The sequences were aligned using the CLUSTAL w program (Higgins et al., 1996) and phylogenetic analyses were carried out using the PHYLIP package (Felsenstein, 2004). Distance and parsimony methods were employed, with 1000 bootstrap analyses.

Sequences of strains $\mathrm{AMO}^{\mathrm{T}}, 20 \mathrm{Z}^{\mathrm{T}}$ and $\mathrm{NI}^{\mathrm{T}}$ displayed relatively high similarity levels (96-97\%) to each other and were closely related to the sequences of Methylomicrobium pelagicum ACM $3505^{\mathrm{T}}$ (96-98\%) and Methylomicrobium buryatense $5 \mathrm{~B}^{\mathrm{T}}(97 \%)$. On the phylogenetic tree all the sequences clustered together, forming a monophyletic group, with high bootstrap values (Fig. 1). The sequences showed lower similarity with the sequences of other halophilic methanotrophic bacteria, such as Methylobacter marinus $\mathrm{A} 45^{\mathrm{T}}(<96 \%)$, Methylosphaera hansonii AM11 ${ }^{\mathrm{T}}$ $(<89 \%)$ and Methylohalobium crimeensis $10 \mathrm{Ki}^{\mathrm{T}}(<91 \%)$. It is notable that sequences of two strains presently classified as Methylomicrobium agile (ATCC $35068^{\mathrm{T}}$ ) and Methylomicrobium album (BG8 ${ }^{\mathrm{T}}$ ) (Bowman et al., 1995) were separated from the sequences of halo(alkali)philic representatives of this genus, Methylomicrobium pelagicum ACM $3505^{\mathrm{T}}$ (Sieburth et al., 1987; Bowman et al., 1995) and Methylomicrobium buryatense $5 \mathrm{~B}^{\mathrm{T}}$ (Kaluzhnaya et al., 2001), and fell instead together with sequences representing the Methylosarcina clade (Bowman et al., 1993) with high bootstrap values (Fig. 1). Close relationships between Methylosarcina species and non-halophilic members of the genus Methylomicrobium were already demonstrated by phylogenetic analysis of particulate methane monooxygenase (pmoA) gene sequences (Wise et al., 2001). Methylobacter species were also divided between three major branches: the first was formed by psychrophilic/-tolerant species (Methylobacter psychrophilus and Methylobacter tundripaludum), the second cluster includes Methylobacter luteus, Methylobacter marinus and 'Methylobacter vinelandii 87, while Methylobacter whittenburyi falls within the Methylomicrobium/Methylosarcina clade. These data indicate that a reclassification of non-halophilic species of the genus Methylomicrobium, as well as significant revision of the genera Methylobacter and Methylosarcina, is needed.

To clarify further the taxonomic status of the strains in question, we performed DNA-DNA hybridization analyses. DNA was extracted as described previously (Kalyuzhnaya et al., 1999) and DNA-DNA hybridization experiments were carried out as described by Johnson (1994). Methylomicrobium pelagicum was not included in these experiments, as it is no longer available in culture. DNADNA relatedness of the halo(alkali)philic/-tolerant methanotrophs is shown in Table 2. These data are in agreement with the 16S rRNA gene phylogeny and indicate that strains $\mathrm{AMO} 1^{\mathrm{T}}, 20 \mathrm{Z}^{\mathrm{T}}$ and $\mathrm{NI}^{\mathrm{T}}$ are more closely related to each other (28-54\%) and to Methylomicrobium buryatense 5G $(22-54 \%)$ than to Methylomicrobium agile ATCC $35068^{\mathrm{T}}$ and Methylomicrobium album $\mathrm{BG} 8^{\mathrm{T}}$ (less than $20 \%$ ). However, the modest level of hybridization between the strains in question indicated that they represent three different species. These data are consistent with the previously described phenotypic differences between the strains (Khmelenina et al., 1997; Kaluzhnaya et al., 2001). Overall genomic characterization confirmed that strains $20 \mathrm{Z}^{\mathrm{T}}, \mathrm{AMO}^{\mathrm{T}}$ and $\mathrm{NI}^{\mathrm{T}}$ should be assigned to the genus Methylomicrobium within novel species, for which we

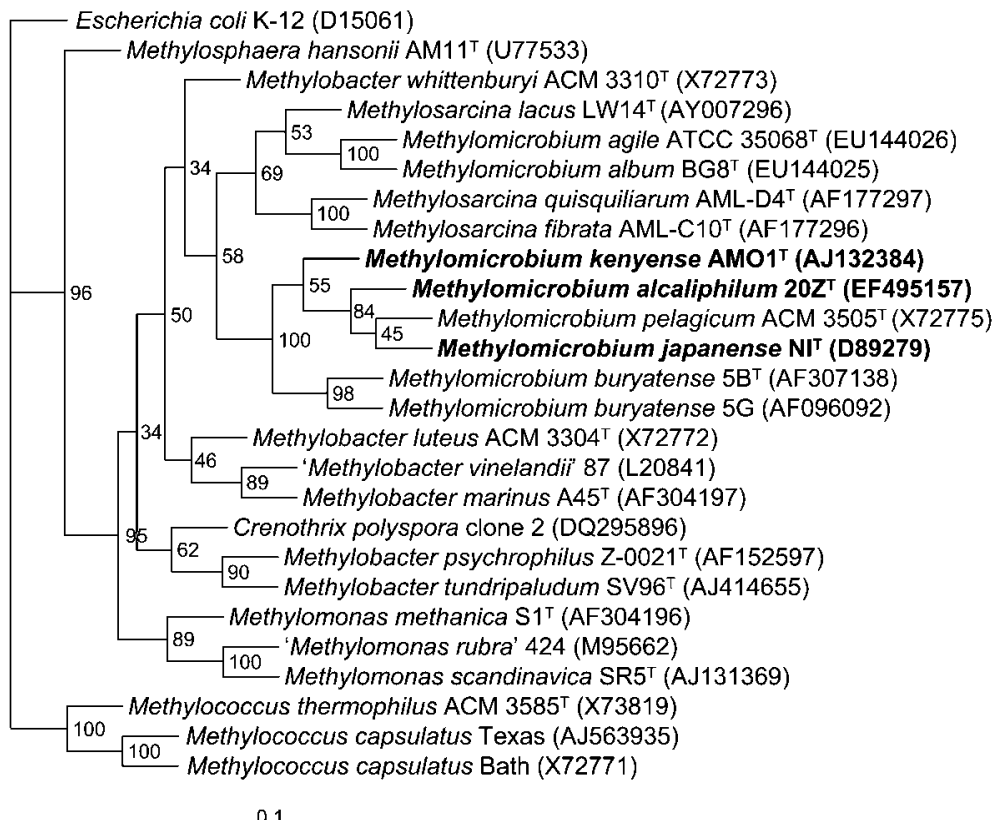

0.1
Fig. 1. $16 \mathrm{~S}$ rRNA gene sequence-based distance dendrogram showing the phylogenetic positions of strains $\mathrm{AMO}^{\top}, 20 \mathrm{Z}^{\top}$ and $\mathrm{NI}^{\top}$ in relation to other type $\mathrm{I}$ and type $\mathrm{X}$ methanotrophs. The 16S rRNA gene sequence of Escherichia coli $\mathrm{K}-12$ was used as an outgroup. Bar, 0.1 changes per nucleotide sequence position. GenBank accession numbers are given in parentheses. 
Table 2. DNA-DNA relatedness (\%) between strains $20 Z^{\top}$, $\mathrm{AMO}^{\top}$ and $\mathrm{NI}^{\top}$ and reference strains

\begin{tabular}{|c|c|c|c|c|c|c|}
\hline Strain & 1 & 2 & 3 & 4 & 5 & 6 \\
\hline 1. Methylobacter sp. $20 \mathrm{Z}^{\mathrm{T}}$ & 100 & & & & & \\
\hline 2. Methylomicrobium sp. $\mathrm{AMO}^{\mathrm{T}}$ & 21 & 100 & & & & \\
\hline 3. Methylomicrobium sp. $\mathrm{NI}^{\mathrm{T}}$ & 45 & 40 & 100 & & & \\
\hline $\begin{array}{l}\text { 4. Methylomicrobium buryatense } \\
5 \mathrm{G}\end{array}$ & 55 & 29 & 54 & 100 & & \\
\hline $\begin{array}{l}\text { 5. Methylomicrobium album } \\
\text { ATCC } 33003^{\text {T }}\end{array}$ & 18 & 17 & 15 & 17 & 100 & \\
\hline $\begin{array}{l}\text { 6. Methylomicrobium agile ATCC } \\
35068^{\mathrm{T}}\end{array}$ & 16 & 17 & 17 & 19 & 47 & 100 \\
\hline
\end{tabular}

propose the names Methylomicrobium alcaliphilum sp. nov., Methylomicrobium kenyense sp. nov. and Methylomicrobium japanense sp. nov., respectively.

\section{Description of Methylomicrobium alcaliphilum sp. nov.}

Methylomicrobium alcaliphilum (al.ca.li.phi'lum. N.L. n. alcali from French n. alcali alkali; Gr. adj. philos loving; N.L. neut. adj. alcaliphilum loving alkaline conditions).

Previously known as 'Methylobacter alcaliphilum'. Gramnegative cells, varying from rods as a major form to cocci and ellipsoids, $1.2-1.3 \times 2.0-3.0 \mu \mathrm{m}$. Reproduces by binary fission. Motile by a single polar flagellum. Cells have type I intracytoplasmic membranes (ICM) and could form surface (S)-layers consisting of cup-shaped subunits, $38 \mathrm{~nm}$ in height and $33 \mathrm{~nm}$ in diameter, arranged in $p 6$ symmetry. Colonies are white to slightly cream, uniform, regularly convex, soft with entire edges. Grows well in the $\mathrm{pH}$ range 7.2-9.5. Does not grow below $\mathrm{pH}$ 7.0. Sodium ions (at $0.05 \mathrm{M}$ ) are required for growth. Tolerates up to $1.5 \mathrm{M} \mathrm{NaCl}$. Accumulates ectoine as a compatible solute during growth in saline media. Methane-consuming activity is fastest at $\mathrm{pH}$ near 9. The $\mathrm{G}+\mathrm{C}$ content of DNA of the type strain is $47.9 \mathrm{~mol} \%\left(T_{\mathrm{m}}\right)$. Major phospholipid fatty acids are iso- $\mathrm{C}_{16: 0}, \mathrm{C}_{16: 0}$ and $\mathrm{C}_{14: 0}$.

The type strain is strain $20 \mathrm{Z}^{\mathrm{T}}\left(=\mathrm{VKM} \mathrm{B}-2133^{\mathrm{T}}=\mathrm{NCIMB}\right.$ $14124^{\mathrm{T}}$ ), isolated from surface sediment of the soda lake Shara-Nur, Tuva, Russian Federation. Reference strain $5 \mathrm{Z}$ (=VKM B-2180) was isolated from the soda lake Khadyn, Tuva.

\section{Description of Methylomicrobium kenyense sp. nov.}

Methylomicrobium kenyense (ken.yen'se. N.L. neut. adj. kenyense pertaining to Kenya).

Gram-negative, large, ovoid rods, sometimes coccoid, 1$1.5 \times 2-3 \mu \mathrm{m}$. Motile by means of flagella. A small fraction of cells may possess up to three peritrichous flagella, while the majority possess a single flagellum. Cells have type I ICM and form an additional subunit S-layer, loosely associated with the cell wall. S-layers consist of small subunits, $1.8 \mathrm{~nm}$ in diameter and $1.5 \mathrm{~nm}$ high, arranged on the cell surface in a hexagonal symmetry. Grows well in the $\mathrm{pH}$ range 9-10.5. Sodium ions are required for growth. Tolerates up to $1.1 \mathrm{M}$ total sodium ion concentration. Ammonia, nitrate and nitrite can be used as nitrogen sources. Oxidizes ammonium to nitrite above $\mathrm{pH} 10.0$. Methane-oxidizing and ammonium-oxidizing activities are maximal at $\mathrm{pH}$ near 10 . The $\mathrm{G}+\mathrm{C}$ content of DNA of the type strain is $50.9 \mathrm{~mol} \%\left(T_{\mathrm{m}}\right)$.

The type strain, strain $\mathrm{AMO}^{\mathrm{T}}\left(=\mathrm{NCCB} 97157^{\mathrm{T}}=\mathrm{VKM} B-\right.$ $2464^{\mathrm{T}}=$ NCIMB $13566^{\mathrm{T}}$ ), was isolated from surface sediments of a Kenyan soda lake.

\section{Description of Methylomicrobium japanense sp. nov.}

Methylomicrobium japanense (ja.pa.nen'se. N.L. neut. adj. japanense pertaining to Japan).

Gram-negative, rod-shaped cells, $0.9-1.2 \times 1.8-2.8 \mu \mathrm{m}$. Reproduces by binary fission. Motile by a single polar flagellum. Cells have type I ICM. Colonies are white to slightly cream, uniform, regularly convex, soft with entire edges. Slightly halophilic; grows between 0.03 and $1.5 \mathrm{M}$ $\mathrm{NaCl}$, optimally at $0.4-0.8 \mathrm{M} \mathrm{NaCl}$. Grows well between 15 and $37{ }^{\circ} \mathrm{C}$; does not grow at or below $4{ }^{\circ} \mathrm{C}$ or at or above $45{ }^{\circ} \mathrm{C}$. The $\mathrm{G}+\mathrm{C}$ content of DNA of the type strain is $49.9 \mathrm{~mol} \%$ (HPLC method). The major fatty acid is $\mathrm{C}_{16: 1}$ $(72-76 \%)$, other significant phospholipid fatty acids are $\mathrm{C}_{14: 0}(3 \%), \mathrm{C}_{16: 0}(11-17 \%)$ and $\mathrm{C}_{16: 0} 3-\mathrm{OH}(0-6 \%)$. Some strains contain soluble methane monooxygenase (sMMO). Liquid culture is often flocculating.

The type strain, $\mathrm{NI}^{\mathrm{T}}\left(=\mathrm{VKM}-\mathrm{B}-2462^{\mathrm{T}}=\right.$ FERM BP-5633 ${ }^{\mathrm{T}}$ $=$ NBRC $103677^{\mathrm{T}}$ ), was isolated from marine mud (Hiroshima, Japan).

\section{Emended description of the genus Methylomicrobium}

Cells are short rods, $0.5-1.5 \times 1.5-3.0 \mu \mathrm{m}$. Motile by a single polar flagellum or three peritrichous flagella. Reproduce by binary fission and unable to form cysts or spores. Cells contain type I ICM as stacks of vesicular discs. Cells may possess a thin slime capsule or regular glycoprotein S-layers arranged in $p 2$ or $p 6$ symmetries. Obligate methanotrophs utilizing methane or methanol as carbon and energy sources but not other $\mathrm{C}_{1}$ or $\mathrm{C}_{n}$ compounds. Assimilate formaldehyde via the ribulose monophosphate pathway. Utilize nitrate and ammonium salts as nitrogen sources. Mesophilic, with optimal growth at $25-30{ }^{\circ} \mathrm{C}$. Some strains are alkalitolerant or alkaliphilic, growing well in the $\mathrm{pH}$ range 9-10.5, and require sodium ions for growth. Possess a particulate MMO, and some strains may also contain a soluble MMO. The most abundant fatty acids are $\mathrm{C}_{16: 1} \omega 7 c, \mathrm{C}_{16: 1}, \mathrm{C}_{16: 0}, \mathrm{C}_{14: 0}$ and $\mathrm{C}_{16: 1} \omega 8 \mathrm{c}$ (only for Methylomicrobium album and 
Methylomicrobium agile). The primary quinone is ubiquinone-8 (Q-8). The G+C content of the DNA is 46$51 \mathrm{~mol} \%$. Member of the family Methylococcaceae in the Gammaproteobacteria. The type species is Methylomicrobium agile.

\section{Acknowledgements}

Authors are thankful to Emily Jackson-Machelski and all members of the ATCC team for careful verification of $16 \mathrm{~S}$ rRNA gene sequences from strains ATCC $33003^{\mathrm{T}}$ and ATCC $35068^{\mathrm{T}}$. We thank Ludmila Chistoserdova for many thoughtful discussions. This study was supported by the grants RFBR 07-04-01064 and 07-04-00153, Ministry of Education and Science RF RNP 2.1.1.2671, CRDF RB12509-MO-03 and MCB-0131957.

\section{References}

Bowman, J. P., Sly, L. I., Nichols, P. D. \& Hayward, A. C. (1993). Revised taxonomy of the methanotrophs: description of Methylobacter gen. nov., emendation of Methylococcus, validation of Methylosinus and Methylocystis species, and a proposal that the family Methylococcaceae includes only the group I methanotrophs. Int J Syst Bacteriol 43, 735-753.

Bowman, J. P., Sly, L. I. \& Stackebrandt, E. (1995). The phylogenetic position of the family Methylococcaceae. Int J Syst Bacteriol 45, 182-185.

Bowman, J. P., McCammon, S. A. \& Skerratt, J. H. (1997). Methylosphaera hansonii gen. nov., sp. nov., a psychrophilic, group I methanotroph from Antarctic marine-salinity, meromictic lakes. Microbiology 143, 1451-1459.

Cho, J.-C. \& Giovannoni, S. J. (2003). Fulvimarina pelagi gen. nov., sp. nov., a marine bacterium that forms a deep evolutionary lineage of descent in the order 'Rhizobiales'. Int J Syst Evol Microbiol 53, 1853-1859.

Dedysh, S. N., Belova, S. E., Bodelier, P. L. E., Smirnova, K. V., Khmelenina, V. N., Chidthaisong, A., Trotsenko, Y. A., Liesack, W. \& Dunfield, P. F. (2007). Methylocystis heyeri sp. nov., a novel type II methanotrophic bacterium possessing 'signature' fatty acids of type I methanotrophs. Int J Syst Evol Microbiol 57, 472-479.

Edwards, U., Rogall, T., Blöcker, H., Emde, M. \& Böttger, E. C. (1989). Isolation and direct complete nucleotide determination of entire genes. Characterization of a gene coding for $16 \mathrm{~S}$ ribosomal RNA. Nucleic Acids Res 17, 7843-7853.

Felsenstein, J. (2004). PHYLIP: phylogeny inference package, version 3.6. Distributed by the author. Department of Genome Sciences, University of Washington, Seattle, USA.

Fuse, H., Ohta, M., Takimura, O., Murakami, K., Inoue, H., Yamaoka, Y., Oclarit, J. M. \& Omori, T. (1998). Oxidation of trichloroethylene and dimethyl sulfide by a marine Methylomicrobium strain containing soluble methane monooxygenase. Biosci Biotechnol Biochem 62, 1925-1931.

Hanson, R. S. \& Hanson, T. E. (1996). Methanotrophic bacteria. Microbiol Rev 60, 439-471.

Heyer, J., Berger, U., Hardt, M. \& Dunfield, P. F. (2005). Methylohalobius crimeensis gen. nov., sp. nov., a moderately halophilic, methanotrophic bacterium isolated from hypersaline lakes of Crimea. Int J Syst Evol Microbiol 55, 1817-1826.

Higgins, I. J., Best, D. J. \& Hammond, R. C. (1980). New findings in methane-utilizing bacteria highlight their importance in the biosphere and their commercial potential. Nature 286, 561-564.

Higgins, D. G., Thompson, J. D. \& Gibson, T. J. (1996). Using CLUSTAL for multiple sequence alignments. Methods Enzymol 266, 383-402.
Johnson, J. L. (1994). Similarity analysis of DNAs. In Methods for General and Molecular Bacteriology, pp. 655-682. Edited by P. Gerhardt, R. G. E. Murray, W. A. Wood \& N. R. Krieg. Washington, DC: American Society for Microbiology.

Kaluzhnaya, M. G., Khmelenina, V. N., Eshinimaev, B. Ts., Suzina, N. E., Nikitin, D., Solonin, A., Lin, J.-L., McDonald, I. R., Murrell, J. C. \& Trotsenko, Y. A. (2001). Taxonomic characterization of new alkaliphilic and alkalitolerant methanotrophs from soda lakes of the Southeastern Transbaikal region and description of Methylomicrobium buryatense sp. nov. Syst Appl Microbiol 24, 166-176.

Kalyuzhnaya, M. G., Khmelenina, V. N., Starostina, N. G., Baranova, S. B., Suzina, N. E. \& Trotsenko, Y. A. (1998). A new moderately halophilic methanotroph of the genus Methylobacter. Microbiology (English translation of Mikrobiologiia) 67, 438-444.

Kalyuzhnaya, M. G., Khmelenina, V. N., Suzina, N. E., Lysenko, A. M. \& Trotsenko, Y. A. (1999). New methanotrophic isolates from soda lakes of the southern Transbaikal region. Microbiology (English translation of Mikrobiologiia) 68, 592-600.

Katayama-Fujimura, Y., Komatsu, Y., Kuraishi, H. \& Kaneko, T. (1984). Estimation of DNA base composition by high performance liquid chromatography of its nuclease P1 hydrolysate. Agric Biol Chem 48, 3169-3172.

Khmelenina, V. N., Kalyuzhnaya, M. G., Starostina, N. G., Suzina, N. E. \& Trotsenko, Y. A. (1997). Isolation and characterization of halotolerant alkaliphilic methanotrophic bacteria from Tuva soda lakes. Curr Microbiol 35, 257-261.

Khmelenina, V. N., Kalyuzhnaya, M. G., Sakharovsky, V. G., Suzina, N. E., Trotsenko, Y. A. \& Gottschalk, G. (1999). Osmoadaptation in halophilic and alkaliphilic methanotrophs. Arch Microbiol 172, 321329.

Lin, J.-L., Radajewski, S., Eshinimaev, B. T., Trotsenko, Y. A., McDonald, I. R. \& Murrell, J. C. (2004). Molecular diversity of methanotrophs in Transbaikal soda lake sediments and identification of potentially active populations by stable isotope probing. Environ Microbiol 6, 1049-1060.

Miller, J. A., Kalyuzhnaya, M. G., Noyes, E., Lara, J. C., Lidstrom, M. E. \& Chistoserdova, L. (2005). Labrys methylaminiphilus sp. nov., a novel facultatively methylotrophic bacterium from a freshwater lake sediment. Int J Syst Evol Microbiol 55, 1247-1253.

Nercessian, O., Kalyuzhnaya, M. G., Joye, S., Lidstrom, M. E. \& Chistoserdova, L. (2005). Analysis of fae and $f h c D$ genes in Mono Lake, California. Appl Environ Microbiol 71, 8949-8953.

Reshetnikov, A. S., Khmelenina, V. N. \& Trotsenko, Y. A. (2006). Characterization of the ectoine biosynthesis genes of haloalkalotolerant obligate methanotroph "Methylomicrobium alcaliphilum 20Z". Arch Microbiol 184, 286-297.

Sieburth, J. M., Johnson, P. W., Eberhardt, M. A., Sieracki, M. E., Lidstrom, M. \& Laux, D. (1987). The first methane-oxidizing bacterium from the upper mixed layer of the deep ocean. Methylomonas pelagica sp. nov. Curr Microbiol 14, 285-293.

Sorokin, D. Y., Jones, B. E. \& Kuenen, J. G. (2000). A novel obligately methylotrophic, methane-oxidizing Methylomicrobium species from a highly alkaline environment. Extremophiles 4, 145-155.

Trotsenko, Y. A. \& Khmelenina, V. N. (2002a). Biology of extremophilic and extremotolerant methanotrophs. Arch Microbiol 177, 123-131.

Trotsenko, Y. A. \& Khmelenina, V. N. (2002b). Biology and osmoadaptation of haloalkaliphilic methanotrophs. Microbiology (English translation of Mikrobiologiia) 71, 123-132.

Trotsenko, Yu. A., Doronina, N. V. \& Khmelenina, V. N. (2005). Biotechnological potential of methylotrophic bacteria: a review of current status and future prospects. Appl Biochem Microbiol (English translation of Prikl Biokhim Mikrobiol) 41, 437-441. 
Wartiainen, I., Hestnes, A. G., McDonald, I. R. \& Svenning, M. M. (2006). Methylobacter tundripaludum sp. nov., a methane-oxidizing bacterium from Arctic wetland soil on the Svalbard islands, Norway $\left(78^{\circ} \mathrm{N}\right)$. Int J Syst Evol Microbiol 56, 109-113.

Whalen, S. C. \& Reeburgh, W. S. (1990). Consumption of atmospheric methane by tundra soils. Nature 346, 160-162.
Whittenbury, R., Phillips, K. C. \& Wilkinson, J. F. (1970). Enrichment, isolation and some properties of methane-utilizing bacteria. J Gen Microbiol 61, 205-218.

Wise, M. G., McArthur, J. V. \& Shimkets, L. J. (2001). Methylosarcina fibrata gen. nov., sp. nov. and Methylosarcina quisquiliarum sp. nov., novel type I methanotrophs. Int J Syst Evol Microbiol 51, 611-621. 